\title{
Hyper Immunoglobulin M Immunodeficiency (Dysgammaglobulinemia)
}

\author{
PRESENCE OF IMMUNOGLOBULIN M-SECRETING PLASMACYTOID \\ CELLS IN PERIPHERAL BLOOD AND FAILURE OF \\ IMMUNOGLOBULIN M-IMMUNOGLOBULIN G SWITCH
}

IN B-CELL DIFFERENTIATION

\begin{abstract}
Raif S. Geha, Newton Hyslop, Samih alami, Fuad Farah, Eveline E. SCHNEEbERGER, and Fred S. Rosen, Departments of Pediatrics, Medicine, and Pathology, Harvard Medical School and Division of Allergy and Immunology, Department of Medicine and Department of Pathology, Children's Hospital Medical Center, and Infectious Disease Unit, Department of Medicine, Massachusetts General Hospital, Boston, Massachusetts 02114; and Departments of Medicine and Pediatrics, American University Medical Center, Beirut, Lebanon
\end{abstract}

A B S T RACT The peripheral blood lymphocytes of nine patients with hyper immunoglobulin (Ig)M immunodeficiency were studied in an attempt to define the cellular basis of this disorder. B cells were normal in number but qualitatively abnormal in all patients. Approximately one-half of the B cell consisted of small lymphocytes (7-9 $\mu \mathrm{m}$ in diameter) bearing surface IgM and IgD, as well as C3 receptors. These cells were driven to secrete IgM but not IgG after in vitro stimulation by pokeweed mitogen. In the blood there were also large lymphocytes (10-14 $\mu \mathrm{m}$ in diameter) that possessed surface as well as intracytoplasmic IgM but lacked C3 receptors. These cells spontaneously secreted large amounts of IgM in vitro and on electron microscopy were found to be rich in rough endoplasmic reticulum. Such a subpopulation of lymphoid cells was not detected in normal peripheral blood and was unique for all patients with hyper IgM immunodeficiency studied.

$T$ cells from all patients were normal in number and in function both in vivo and in vitro and were able to generate adequate T-cell help to support IgG synthesis by normal B cells. No evidence was obtained for T cells capable of suppressing normal IgG synthesis in any of the patients after coculture with normal peripheral

Received for publication 14 August 1978 and in revised form 26 March 1979. blood lymphocytes. The defect in hyper IgM immunodeficiency is intrinsic to B cells, which fail to switch from IgM to IgG synthesis.

\section{INTRODUCTION}

An immunodeficiency disease has been characterized in both an X-linked and acquired form in patients whose sera contain increased amounts of immunoglobulin (Ig)M and IgD and are markedly deficient in the other immunoglobulins (1). Patients affected with hyper IgM immunodeficiency are extremely susceptible to recurrent pyogenic infections, to autoimmune disease induced by IgM antibodies (2), and to a malignant lymphoproliferative disease of IgM-producing B cells (3).

The IgM-producing B lymphocytes were characterized in lymphoid tissues of these patients by Cruchaud et al. (4). Since that time, experimental models of the disease have been evoked by blocking the maturation of $\mathrm{B}$ cells at various stages of their ontogeny (5). The present study was undertaken to characterize $B$ cells in the blood of nine patients with hyper IgM immunodeficiency.

\section{METHODS}

The objectives of the study were explained to the patients or their parents and consent was obtained. 


\section{Intradermal skin tests for delayed hypersensitivity}

Intradermal skin tests were performed with $0.1 \mathrm{ml}$ of the following antigens diluted in sterile saline: streptokinasestreptodornase (Varidase, The Lilly Research Laboratories, Eli Lilly \& Co., Indianapolis, Ind.), 40 U Streptokinase, $10 \mathrm{U}$ streptodornase; Candida antigen (Dermatophytin O, HollisterStier Laboratories), diluted 1:50.

\section{Isolation of peripheral blood lymphocytes $(P B L)^{1}$}

Mononuclear cells were obtained from peripheral blood of healthy volunteer, adult human donors by Ficoll-Hypaque (Pharmacia Fine Chemicals, Inc., Piscataway, N. J.) density gradient centrifugation. After washing three times in Hanks' balanced salt solution (Microbiological Associates, Walkersville, Md.), the cells were resuspended in RPMI 1640 (Microbiological Associates) supplemented with penicillin $(100 \mathrm{U} / \mathrm{ml})$, streptomycin $(100 \mu \mathrm{g} / \mathrm{ml})$, and $10 \%$ heat-inactivated serum obtained from human donors with type AB, Rh+ erythrocytes (complete culture medium).

\section{Rosette formation with sheep erythrocyte intermediates}

Sheep erythrocyte (6) intermediates EA, EAC14, and EAC1423 were prepared with human components of complement (6) and adjusted to a final concentration of $1 \%$ in phosphate-buffered saline (PBS). Lymphocyte suspensions were adjusted to $2 \times 10^{6} \mathrm{cells} / \mathrm{ml}$ in PBS that contained $10 \%$ serum from a donor with type $\mathrm{AB}, \mathrm{Rh}+$ erythrocytes and $\mathrm{ab}-$ sorbed three times with sheep erythrocytes $(E)$. Equal volumes of lymphocyte and $E$ or E-intermediate suspensions were mixed. Tubes that contained $\mathbf{E}$ and $\mathbf{E A}$ were incubated for $30 \mathrm{~min}$ at room temperature, whereas those that contained EAC1423 and EACl4 were incubated for the same period of time at $37^{\circ} \mathrm{C}$. After this initial incubation, all tubes were centrifuged at $200 \mathrm{~g}$ for $5 \mathrm{~min}$ at $4^{\circ} \mathrm{C}$ and the pellets were incubated at $4^{\circ} \mathrm{C}$ for $1 \mathrm{~h}$. Cells were then resuspended and examined microscopically. Lymphocytes intimately associated with more than four erythrocytes were counted.

\section{Immunofluorescent staining}

Immunofluorescence was performed with commercially obtained (N. L. Cappel Laboratories Inc., Cochranville, Pa.), fluorescein-conjugated antisera raised in goats against human immunoglobulins (polyvalent), IgM, and human IgD myeloma proteins. These two latter antisera were rendered monospecific by absorption over the appropriate IgG, IgM, or IgD myeloma proteins coupled to Sepharose 4B (Pharmacia Fine Chemicals, Inc.). Surface immunofluorescence was performed by adding $0.1 \mathrm{ml}$ of conjugated antiserum to an equal volume of a suspension containing $5 \times 10^{6} \mathrm{cells} / \mathrm{ml}$ of Medium 199 supplemented with $5 \%$ fetal calf serum and $5 \mathrm{cM}$ sodium azide. Cells were incubated for $45 \mathrm{~min}$ at $4^{\circ} \mathrm{C}$, washed three times at $4^{\circ} \mathrm{C}$ in the medium described above, and transferred to a glass slide in a drop of glycerol:PBS (9:1).

${ }^{1}$ Abbreviations used in this paper: BSA, bovine serum albumin; E, sheep erythrocyte; LMF, lymphocyte mitogenic factor; PBL, peripheral blood Iymphocyte(s); PBS, phosphate-buffered saline; PWM, pokeweed mitogen; TT, tetanus toxoid.
Slides were examined with a Zeiss fluorescent microscope (Carl Zeiss, Inc., New York). At least 200 cells were examined and the percentage of fluorescent cells recorded.

Intracytoplasmic staining was performed by preparing cytocentrifuge smears with $0.1 \mathrm{ml}$ of cell suspension at a concentration of $5 \times 10^{6} \mathrm{cell} / \mathrm{s} / \mathrm{ml}$. The slides were fixed in a precooled $\left(-20^{\circ} \mathrm{C}\right)$ mixture of ethanol $(100$ parts $)$ and glacial acetic acid ( 5 parts) for $10 \mathrm{~min}$. The slides were then rehydrated by washing in three changes of PBS of 5 min each. Staining was performed in a humid chamber by applying a drop of the conjugated antiserum on the cell smear for $30 \mathrm{~min}$ at room temperature. The slides were then washed in three changes of PBS and mounted in PBS-glycerol.

\section{Fractionation of lymphocytes on gradients of bovine serum albumin (BSA)}

Lymphocytes were fractionated on discontinuous gradients of BSA (Sigma Chemical Co., St. Louis, Mo.) by a modification of the method of Dicke et al. (6). Gradients were formed in $16 \times 125 \mathrm{~mm}$ plastic tubes by layering $1 \mathrm{ml}$ of the albumin solutions in $2 \%$ decrements, starting with $35 \%$ and ending with $19 \%$ solutions. $1 \times 10^{8}$ cells were suspended in $1 \mathrm{ml}$ of $17 \%$ BSA and layered on top of the gradient. Tubes were centrifuged at $10^{\circ} \mathrm{C}$ and $900 \mathrm{~g}$ for $45 \mathrm{~min}$. Nine fractions were obtained: fraction 1 represents cells at the interface between 17 and 19\% albumin; and fraction 9, those between 33 and $35 \%$ albumin. Cells that sediment in the middle portion of the BSA gradient (fractions 23-27\% BSA) have been shown to be enriched in $\mathrm{T}$ lymphocytes (80-85\% form $\mathrm{E}$ rosettes) (6).

\section{Preparation of B-cell rich populations}

Various fractions of the BSA gradient were enriched for B cells by isolation of the E nonrosette-forming cells from these fractions followed by depletion of adherent cells. After rosette formation with $\mathrm{E}$, the $\mathrm{E}$ nonrosette-forming cells were separated over a Ficoll gradient, washed, resuspended at a concentration of $1 \times 10^{6} \mathrm{ml}$, and distributed into plastic Petri dishes (Falcon Labware, Div of Becton, Dickinson \& Co., Oxnard, Calif.). After an incubation period of $1 \mathrm{~h}$ at $37^{\circ} \mathrm{C}$ the nonadherent cells were gently aspirated with a Pasteur pipette, washed in Hanks' balanced salt solution, and resuspended in complete culture medium (7).

\section{Electron microscopy}

Cell pellets of lymphocytes were fixed in $2 \%$ glutaraldehyde in $0.1 \mathrm{M}$ cacodylate buffer, $\mathrm{pH} 7.4$, that contained $0.1 \mathrm{M}$ sucrose, and $4.5 \mathrm{mM} \mathrm{CaCl}_{2}$ for $1 \mathrm{~h}$ at $4^{\circ} \mathrm{C}$. They were rinsed three times in $0.1 \mathrm{M}$ cacodylate buffer, $\mathrm{pH} 7.4$, that contained $0.1 \mathrm{M}$ sucrose and postfixed in $2 \%$ aqueous $\mathrm{OsO}_{4}$ for $1 \mathrm{~h}$ at $4^{\circ} \mathrm{C}$. The cells were stained en bloc with $1.5 \%$ uranyl acetate in $0.5 \mathrm{M}$ maleate buffer, pH 6.2, and dehydrated in graded ethanol and embedded in Epon (Shell Chemical Co., Houston, Tex.). Thin sections were cut with a diamond knife (DuPont Instruments, Wilmington, Del.) on an LKB Ultratome III (LKB Instruments, Inc., Rockville, Md.) and picked up on carbon-coated grids. They were stained with lead citrate and examined in a Philips 300 electron microscope (Philips Electronic Instruments, Inc., Mahwah, N. J.).

\section{Proliferative response to mitogens and antigens}

Lymphocyte suspensions were cultured in complete culture medium at a concentration of $1 \times 10^{6} \mathrm{cell} / \mathrm{s} / \mathrm{ml}$ in plastic microtiter culture wells (Falcon Labware) in the presence or ab- 
sence of mitogen or antigen. Cultures were incubated for $3 \mathrm{~d}$ with the mitogens phytohemagglutinin-P (Difco Laboratories, Detroit, Mich., final dilution, 1:500), concanavalin A (Calbiochem-Behring Corp., American Hoechst Corp., San Diego, Calif., $50 \mu \mathrm{g} / \mathrm{ml}$ ), and pokeweed mitogen (PWM) (Grand Island Biological Co., Grand Island, N. Y., final dilution 1:100) and for $6 \mathrm{~d}$ with tetanus toxoid (TT). (Massachusetts Biological Laboratories, $10 \mu \mathrm{g} / \mathrm{ml}$ ). In all patients there was a known history of immunizations with TT. Cultures were pulsed with $\left[{ }^{3} \mathrm{H}\right]$ thymidine $(2.0 \mathrm{Ci} / \mathrm{mM}$, New England Nuclear, Boston, Mass.) and $16 \mathrm{~h}$ later the degree of $\left[{ }^{3} \mathrm{H}\right]$ thymidine incorporated into DNA was determined with a tissue culture automatic harvester (Flow Laboratories, Inc., Rockville, Md.). Results were expressed as counts per minute of $\left[{ }^{3} \mathrm{H}\right]$ thymidine incorporated per culture and as stimulation indices (SI) where: $\mathrm{SI}=$ counts per minute of $\left[{ }^{3} \mathrm{H}\right]$ thymidine incorporated per stimulated culture/counts per minute of $\left[{ }^{3} \mathrm{H}\right]$ thymidine incorporated per unstimulated culture.

\section{Preparation of T-cell helper factor}

The basic design for the production of $\mathrm{T}$-cell supernates that contained lymphocyte mitogenic factor (LMF) has been described (8). Briefly, PBL were cultured in complete medium at $1 \times 10^{7} / \mathrm{ml}$ for $48 \mathrm{~h}$. One set of cultures received antigen TT $(10 \mu \mathrm{g} / \mathrm{ml}$ ) at the onset of the incubation period and were designated preincubated $(\mathrm{P})$ cultures. A duplicate set of cultures received an equivalent amount of antigen at the end of the incubation period and were designated reconstituted $(R)$ cultures. The incubation was terminated by pelleting the cells $(200 \mathrm{~g}$ for $10 \mathrm{~min}$ ). The supernates of the cultures were collected, filtered through a $0.22 \mu \mathrm{M}$ Millipore filter (Millipore Corp., Bedford, Mass.), and stored at $-20^{\circ} \mathrm{C}$ until testing.

\section{Mitogenesis and immunoglobulin synthesis by $B$ cells}

Mitogenesis. B lymphocytes were cultured in $0.2 \mathrm{ml}$ cultures in the wells of microtiter plates (Falcon Labware) at a concentration of $1 \times 10^{6} \mathrm{cell} / \mathrm{s} / \mathrm{ml}$ in the presence of PWM or a 0.5 dilution of T-cell supernates. After an incubation period of $6 \mathrm{~d}$ the degree of $\left[{ }^{3} \mathrm{H}\right]$ thymidine incorporated into DNA was determined. Results were expressed as counts per minute of $\left[{ }^{3} \mathrm{H}\right]$ thymidine incorporated per culture. and as mitogenic index (MI) where: $\mathrm{MI}=$ counts per minute of $\left[{ }^{3} \mathrm{H}\right]$ thymidine incorporated in $\mathrm{P}$-stimulated culture/counts per minute of $\left[{ }^{3} \mathrm{H}\right]$ thymidine incorporated in R-stimulated culture.

Immunoglobulin synthesis. B-cell rich suspensions were cultured at $2 \times 10^{6}$ cells $/ \mathrm{ml}$ in $16 \times 125 \mathrm{~mm}$ sterile Falcon plastic culture tubes in the presence of PWM or of a 0.5 dilution of T-cell supernates. Because B-cell rich suspensions were depleted of $T$ cells by a single E-rosetting step, enough contaminating $T$ cells were left behind to allow the $B$ cells to respond to PWM. After a 5-d incubation period the cell pellets were thoroughly washed in Hanks' balanced buffer solution and resuspended at $4 \times 10^{6} / \mathrm{ml}$ in fresh RPMI 1640 medium deficient in L-valine, L-leucine, and L-isoleucine, and supplemented with ${ }^{14} \mathrm{C}$-radiolabeled amino acids $(200 \mathrm{Ci} / \mathrm{mM}$, New England Nuclear) $(2 \mu \mathrm{Ci} / \mathrm{ml})$ and with $10 \%$ dialyzed fetal calf serum (Microbiological Associates). $48 \mathrm{~h}$ later the supernates of the cultures were harvested, filtered through a $0.22 \mu \mathrm{M}$ Millipore filter, and frozen at $-20^{\circ} \mathrm{C}$ until tested. The amount of newly made IgM and IgG present in these supernates was determined by a sandwich radioimmunoassay with $20 \mu \mathrm{g}$ of human IgG or $20 \mu \mathrm{g}$ of human IgM (Waldenström's macroglobulin) and rabbit anti-human IgG or antihuman IgM at equivalence as described (8). The precipitates were washed twice in PBS, were twice dissolved in $0.1 \mathrm{~N}$ acetic acid, and then reprecipitated with an equal volume of $0.1 \mathrm{~N}$ sodium hydroxide. The precipitates were finally dissolved in $0.1 \mathrm{~N}$ acetic acid and their radioactivity was counted in a liquid scintillation counter (Tri Carb, Packard Instrument Co., Inc., Downers Grove, Ill.) with Aquasol (New England Nuclear) for scintillation fluid.

The spontaneous mitotic and synthetic activity of B cells was determined by incubating freshly isolated cells for $24 \mathrm{~h}$ in the presence of $\left[{ }^{3} \mathrm{H}\right]$ thymidine or ${ }^{14} \mathrm{C}$-amino acids and determining the radioactivity incorporated into DNA and into de novo secreted immunoglobulins, respectively.

\section{One-way mixed lymphocyte cultures}

Stimulator cells were depleted of adherent cells as described above, and irradiated with 3,000 rad using a Cesium source (Gammator M Series, Kewaunee Scientific Equipment Corp., Adrian, Mich.) immediately before their addition to responder cells at a 1:1 ratio. Cultures were incubated at a final cell concentration of $1 \times 10^{6}$ cells $/ \mathrm{ml}$ for $6 \mathrm{~d}$, then assayed for DNA synthesis as described previously.

\section{Suppressor cell assay}

The capacity of patients' cells to suppress IgG synthesis and secretion by normal PBL was asayed as described by Waldmann et al. (9). Patients' PBL at $2 \times 10^{6}$ cells $/ \mathrm{ml}$ were mixed with an equal volume of PBL at $2 \times 10^{6}$ cells $/ \mathrm{ml}$ from a normal adult donor. Aliquots of the mixture were incubated in the presence or absence of PWM and assayed for their capacity to secrete Ig into their supernates as described above. Ig secreted by the mixed-cell population was compared to that secreted by individual components of the mixture (i.e., patients' cells alone and normal donor cells alone) incubated under similar conditions. A measure of the degree of suppression of immunoglobulin production, the coculture index (CCI) was defined as: $\mathrm{CCI}=2 \times$ counts per minute patients' cells + normal cells cocultured with PWM $) /($ counts per minute patients cells + PWM $)+($ counts per minute normal cells + PWM).

In our laboratory, coculture of lymphocytes from 16 pairs of normal donors has yielded a coculture index of $1.04 \pm 0.20$ for IgG and $0.9 \pm 0.15$ for Ig.M. Enhancement or suppression occurs when the coculture index deviates more than $2 \mathrm{SD}$ above or below the mean, respectively.

\section{Miscellaneous studies}

The ability of sera from different patients to inhibit lymphocyte transformation was determined by substitution of patient serum for normal serum in various experiments. Cytotoxicity of patients' sera to B and T lymphocytes isolated from normal donors was determined by the method of Terasaki et al. (10). Lymphoblastoid cell lines were established from the patients; blood lymphocytes with Epstein-Barr virus (11).

\section{RESULTS}

The age, sex, and serum immunoglobulin levels of the nine patients are shown in Table I. It should also be noted in the same table that all the patients had a normal number of peripheral blood $T$ cells as measured by $E$ rosettes and that these cells responded normally to phytohemagglutinin. Skin tests with streptokinase- 
TABLE I

Immunologic Laboratory Findings in Patients with Hyper IgM Immunodeficiency

\begin{tabular}{|c|c|c|c|c|c|c|c|c|c|c|c|}
\hline \multirow[b]{3}{*}{ Patient } & \multirow[b]{3}{*}{ Sex } & \multirow[b]{3}{*}{ Age } & \multirow{2}{*}{\multicolumn{3}{|c|}{ Serum immunoglobulins }} & \multirow{3}{*}{$\begin{array}{c}E \\
\text { rosettes }\end{array}$} & \multirow{3}{*}{$\begin{array}{c}\text { PHA } \\
\text { SI }\end{array}$} & \multirow{3}{*}{$\begin{array}{c}\mathrm{EACl} 1423 \\
\text { rosettes }\end{array}$} & \multicolumn{3}{|c|}{ Cells with surface staining } \\
\hline & & & & & & & & & & & Polyvalent \\
\hline & & & IgG & IgM & IgA & & & & IgM & IgD & anti-Ig \\
\hline & & $y r$ & & $m g / d l$ & & $\%$ & & $\%$ & & $\%$ & \\
\hline 1 & $\mathbf{M}$ & 19 & $<10$ & 1,700 & $<5$ & 57 & 77 & 12 & 17 & 11 & 19 \\
\hline 2 & $\mathrm{~F}$ & 8 & $<10$ & 1,220 & $<5$ & 53 & 84 & 10 & 16 & 9 & 18 \\
\hline 3 & $\mathbf{F}$ & 9 & 120 & 1,700 & $<5$ & 63 & 122 & 15 & 21 & 14 & 24 \\
\hline 4 & $\mathbf{M}$ & 3 & 220 & 530 & $<5$ & 52 & 116 & 13 & 19 & 12 & 20 \\
\hline 5 & $\mathbf{M}$ & 6 & 40 & 400 & 18 & 60 & 87 & 13 & 17 & 13 & 17 \\
\hline 6 & $\mathbf{M}$ & 12 & 115 & 300 & $<5$ & 73 & 106 & 12 & 20 & 13 & 23 \\
\hline 7 & $\mathbf{F}$ & 44 & 150 & 520 & 15 & 58 & 94 & 14 & 18 & 10 & 22 \\
\hline 8 & $\mathrm{~F}$ & 55 & 80 & 440 & $<5$ & 66 & 81 & 17 & 21 & 12 & 20 \\
\hline 9 & $\mathbf{M}$ & 4 & 190 & 3,300 & $<5$ & 51 & 71 & 16 & 17 & 11 & 20 \\
\hline \multicolumn{3}{|c|}{ Normal adult range } & $600-1,500$ & $50-200$ & $60-290$ & $52-71$ & $76-148$ & $12-23$ & $6-18$ & $4-13$ & $9-22$ \\
\hline
\end{tabular}

streptodornase and Candida antigens were positive in all eight patients tested. The proliferative response of PBL to stimulation with concanavalin A, PWM, and TT antigen was also normal in all nine patients. Normal amounts of LMF that was able to induce both IgM and IgG synthesis in normal B cells, was released by $\mathrm{T}$ cells of all the patients. The total number of IgMand IgD-bearing B cells in the peripheral blood was within normal limits or increased in all nine patients (Table I).

When B cells from normal donors are separated on BSA density gradients $70-80 \%$ of them sediment in fractions $6-9(27-35 \% \mathrm{BSA})$ and $<5 \%$ sediment in fraction 3 (21-33\% BSA). In all nine patients there was a slight decrease in the proportion of B cells in the lower fractions of the gradient (fractions 6-9), whereas the proportion of $B$ cells in fraction 3 was increased (Fig. 1 and Table II). Those cells that were less dense and sedimented in fraction 3 were large lymphoid cells (10-14 $\mu \mathrm{m}$ in diameter) whose surface stained weakly with anti-mu chain antiserum, and hardly at all with anti-delta chain antiserum; they lacked C3 receptors and constituted 36\% of the cells found in this fraction of the patients' lymphocytes (Table II). Cells with similar characteristics were not found in the same fraction of peripheral blood from normal donors. Fluorescent staining of the cells in this gradient fraction revealed the presence of abundant intracytoplasmic IgM. Electron microscopy of these cells revealed a large nucleus, abundant cytoplasm, and a well-developed rough endoplasmic reticulum (Fig. 2). It was concluded that these cells are IgM secretory plasmacytoid cells. This assumption was verified by incorporation of radioactive leucine, valine, and isoleucine into newly synthesized IgM secreted in the culture fluid supernates of these cells.
They also exhibited high spontaneous rates of DNA synthesis as assessed by incorporation of $\left[{ }^{3} \mathrm{H}\right]$ thymidine (Table III). These rates of DNA and IgM synthesis did not increase after PWM or LMF stimulation.

The in vitro behavior of $B$ cells derived from fractions 6-9 differed from that of $B$ cells obtained from fraction 3 of the BSA gradient. Patients' B cells that sedimented in fractions 6-9 of the BSA gradient had physical characteristics similar to those of normal B cells (Table II). They were small in size (7-10 $\mu \mathrm{m}$ in diameter) and had strong reactivity with EAC1423 (70-80\%). Whereas double fluorescent staining experiments were not performed, from the results obtained with individual fluorescein-conjugated antisera to $\operatorname{IgM}, \operatorname{IgD}$, and human

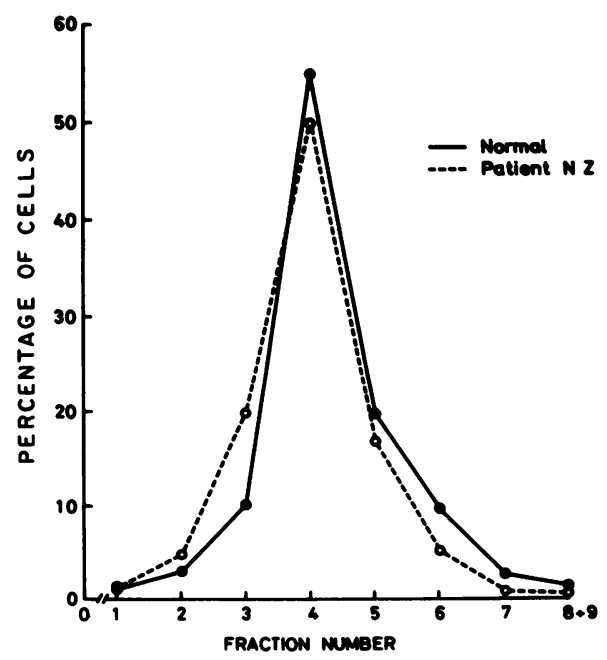

FIGURE 1 Relative distribution PBL of normal subjects and of patients with hyper IgM immunodeficiency on gradients of BSA. 
TABLE II

Comparison of B Cells in BSA Fraction 3 and Fractions 6-9 in Patients with Hyper IgM Immunodeficiency and in Normal Patients

\begin{tabular}{lccccc}
\hline & \multicolumn{2}{c}{ BSA fraction 3 } & & \multicolumn{2}{c}{ BSA fractions 6-9 } \\
\cline { 2 - 3 } \cline { 5 - 6 } & Patients & Controls & & Patients & Controls \\
\hline $\begin{array}{c}\text { Percentage of total* } \\
\text { B-cell number }\end{array}$ & $36 \pm 9$ & $4 \pm 2$ & & $48 \pm 14$ & $72 \pm 13$ \\
$\begin{array}{c}\text { Percentage of EAC1423 } \\
\text { rosettes } \ddagger\end{array}$ & $18.6 \pm 7.8$ & $95.1 \pm 20.7$ & & $83.3 \pm 17.7$ & $87.0 \pm 11.1$ \\
$\begin{array}{c}\text { Percentage of cells with } \\
\text { membrane IgM } \ddagger\end{array}$ & $95.3 \pm 21.9$ & $80.3 \pm 18.3$ & & $78.3 \pm 15.4$ & $78.1 \pm 18.0$ \\
$\begin{array}{c}\text { Percentage of cells with } \\
\text { membrane IgD } \$\end{array}$ & $14.4 \pm 7.5$ & $52.1 \pm 13.1$ & & $71.6 \pm 21.8$ & $60.7 \pm 11.5$ \\
\hline
\end{tabular}

* (B-cell number in the BSA fraction/total B-cell number $) \times 100$. B cell number was determined by enumerating the cells that stained with fluorescein-conjugated polyvalent goat anti-human immunoglobulin antiserum.

$\$$ (Number of cells positive for the marker/number of B cells in the BSA fraction) $\times 100$.

immunoglobulin (polyvalent) shown in Table II, we would infer that some of the cells must contain both mu and delta chain markers. Otherwise, the percentage of cells staining with either anti-IgM or anti-IgD should

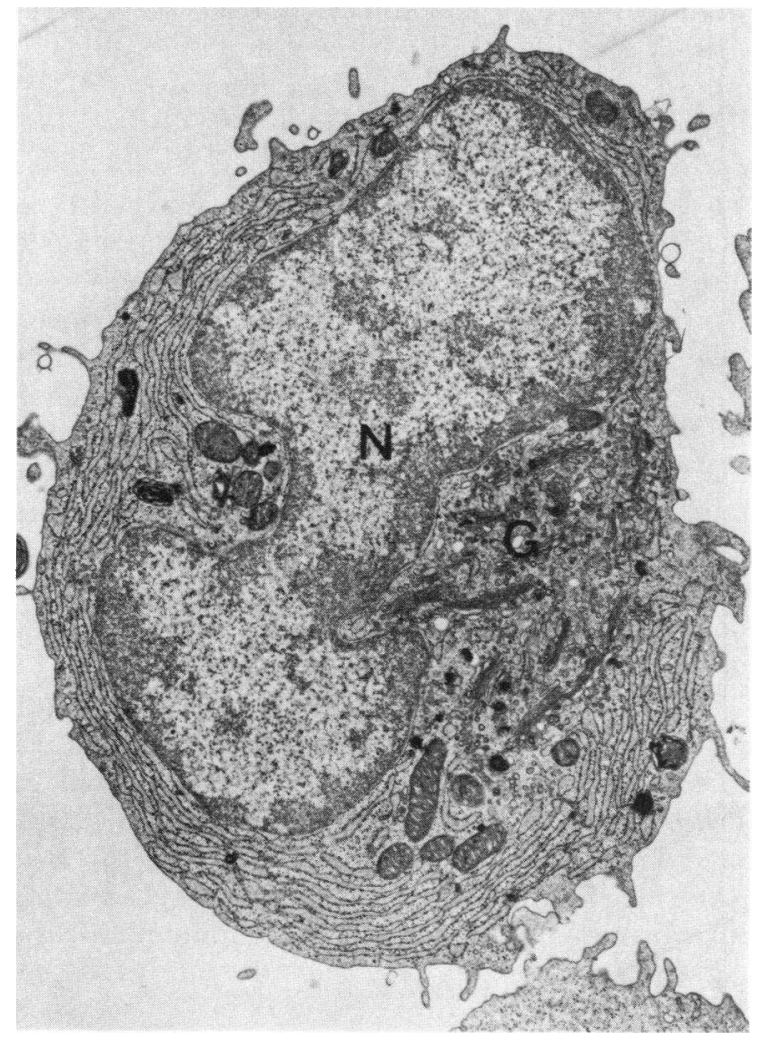

FIGURE 2 Electron micrograph of a plasmacytoid cell from patient No. 3. The nucleus (N) and Golgi apparatus (G) are indicated. The cytoplasm is filled with a large amount of rough endoplasmic reticulum. $\times 8,400$. not exceed $100 \%$. Electron microscopy revealed that these cells possessed a scanty cytoplasm with very little amounts of endoplasmic reticulum and were indistinquishable from normal B cells. However, the B cells of the patients differed from normal B cells in that they did not increase their basal rate of IgG synthesis after PWM stimulation. (Table III).

Miscellaneous studies. None of the sera from the patients was cytotoxic to normal human B or T cells. None of these sera inhibited proliferation and IgG synthesis of normal B cells after stimulation with PWM.

PBL from all nine patients generated normal amounts of the T-cell helper factor (LMF) after stimulation with TT antigen. LMF from all patients caused normal B cells to engage in DNA synthesis and IgM secretion to the same extent as LMF derived from controls.

No suppressor activity for PWM-induced IgG or IgM synthesis was detected in the PB of seven patients tested upon coculture with PBL from normal donors.

Lymphocytes from seven of the patients rendered free of macrophages served as good stimulators in oneway mixed lymphocyte cultures. Furthermore, lymphoblastoid cell lines were established successfully with Epstein-Barr virus from five out of six patients tested. These cell lines secreted exclusively IgM into their supernates and served as good stimulators in one-way mixed lymphocyte cultures.

\section{DISCUSSION}

This study of the PBL of nine patients with hyper IgM immunodeficiency has revealed a unique cellular abnormality. All nine patients had a very significant number of plasmacytoid cells in their blood that were synthesizing and secreting IgM. Such cells are not detected in normal peripheral blood. The peripheral 
TABLE III

In Vitro Behavior of B Cell-Rich BSA Fractions in Patients with Hyper IgM Immunodeficiency and in Controls*

\begin{tabular}{|c|c|c|c|c|}
\hline & \multicolumn{2}{|c|}{ Fraction 3} & \multicolumn{2}{|c|}{ Fractions 6-9 } \\
\hline & Patients & Controls & Patients & Controls \\
\hline & \multicolumn{2}{|c|}{$c p m$} & \multicolumn{2}{|c|}{$c p m$} \\
\hline $\begin{array}{l}\text { Spontaneous }\left[{ }^{3} \mathrm{H}\right] \text { thymidine } \\
\text { incorporation }\end{array}$ & $7,163 \pm 2,384$ & $1,035 \pm 316$ & $752 \pm 227$ & $921 \pm 307$ \\
\hline IgM synthesis & & & & \\
\hline Spontaneous & $5,804 \pm 1,733$ & - & $327 \pm 144$ & $208 \pm 60$ \\
\hline PWM-induced & $1,710 \pm 806$ & - & $2,233 \pm 582$ & $2,872 \pm 735$ \\
\hline \multicolumn{5}{|l|}{ IgG synthesis } \\
\hline Spontaneous & $55 \pm 106$ & - & $286 \pm 67$ & $242 \pm 59$ \\
\hline PWM-induced & $28 \pm 49$ & - & $327 \pm 181$ & $3,105 \pm 862$ \\
\hline
\end{tabular}

* Values represent the mean \pm SD for the nine patients and for eight controls matched for age and sex.

$\downarrow$ Too few control B cells could be purified from fraction 3 to carry synthetic studies.

blood of the patients contained a normal number of $B$ lymphocytes that differed from the B lymphocytes of normal individuals in that in vitro PWM could induce an increase in their rate of IgM synthesis but not of IgG synthesis. All nine patients had normal T-cell number and function. There was no evidence for suppressor cells or serum factors that impeded the normal maturation of their B lymphocytes. The results indicate that the B cells in hyper IgM immunodeficiency fail to differentiate in vivo and in vitro into IgG synthesizing cells.

In the ontogeny of B lymphocytes, IgM, and IgD are first expressed as surface membrane immunoglobulins (12). The subsequent ontogeny of the B lymphocytes is manifested by the surface expression of all the immunoglobulins together with their synthesis for secretion. The generation of isotypic diversity can be blocked in newborn mice by the administration of antiserum to the heavy chain of the IgM (anti-mu) (13). There was no evidence for anti-IgM antibodies in the patients studied. Bursectomy of chick embryos before hatching results in hyper IgM immunodeficiency with low specific antibody titers, a condition resembling the clinical syndrome observed in these patients. As no equivalent organ to the bursa is known in mammals it is difficult to envision that a discrete anatomical lesion could result in hyper IgM immunodeficiency.

Blaese et al. (14) have shown that transfer of cells from immunodeficient bursectomized chicken to normal chickens render the recipients agammaglobulinemic. These suppressor cells, however, develop in the bird sometime after bursectomy apparently in response to antigens in the environment similar to these on normal B cells. No evidence for such suppressor cells was obtained in any of the patients.

Ia antigens are cell membrane components that are the gene products of the major histocompatibility locus in man and mouse. They are found principally on the cell membrane of B cells and macrophages and are the antigens responsible for the mixed lymphocyte reaction. Press et al. (15) have demonstrated in mice that expression of Ia antigens in B lymphocytes is a prerequisite for IgG synthesis but not for IgM synthesis. Therefore, B cells that are Ia negative may synthesize and secrete IgM only but not IgG. The human analogues of the Ia antigens were present on the B lymphocytes of the patients. This was demonstrated by the normal capacity of their purified B cells and of their lymphoblastoid cell lines to serve as stimulators in one-way mixed lymphocyte cultures.

The etiology of the block of normal B-cell maturation in the patients studied remains unknown. Feedback regulation of IgM synthesis by IgG has been proposed but not proven (16), and gamma globulin replacement therapy results only rarely in a decrease in the circulating levels of IgM. Continuous antigenic stimulation, because of the recurrent infections and the poor quality of specific IgM antibody produced, could result in an over-compensatory increase in the quantity of IgM produced.

The patients described in this study reflect the heterogeneity of hyper IgM immunodeficiency. Five of the nine cases occurred in two families, a sixth case followed congenital rubella infection. Yet, all the patients share the same maturation block of the $B$ cell at the stage of the switch from IgM to IgG synthesis with subsequent development of supranormal levels of IgM.

\section{ACKNOWLEDGMENTS}

The authors are indebted to Mrs. Susan Mann and to Miss Virginia Salameh for technical assistance.

This was supported by U. S. Public Health Service grants 
AI-11419, AI-05877, RR-128, and AM-16392; the JoAnne Paley Memorial Fund; the Hood Foundation; and by a Basil

O'Connor Starter grant, National Foundation, March of Dimes.

\section{REFERENCES}

1. Rosen, F. S., and C. A. Janeway. 1966. The gamma globulins: III. The antibody deficiency syndromes. $N$. Engl. J. Med. 275: 709-715.

2. Hinz, C. F., Jr., and J. T. Boyer. 1963. Dysgammaglobulinemia in an adult manifested as autoimmune hemolytic anemia: serologic and immunochemical characterization of antibody of unusual specificity. N. Engl. J. Med. 269: 1329-1335.

3. Hobbs, J. R., A. Russell, and S. M. Worlledge. 1967. Dysgammaglobulinemia type IV C. Clin. Exp. Immunol. 2: 589-599.

4. Cruchaud, A., F. S. Rosen, J. M. Craig, and D. Gitlin. 1962. The site of synthesis of the $19 \mathrm{~S} \gamma$-globulins in dysgammaglobulinemia. J. Exp. Med. 115: 1141-1146.

5. van Alten, P. J., W. A. Cain, R. A. Good, and M. D. Cooper. 1968. Gamma globulin production and antibody synthesis in chicken bursectomized as embryos. Nature (Lond.). 217: 358-360.

6. Geha, R. S., F. S. Rosen, and E. Merler. 1973. Identification and characterization of subpopulations of lymphocytes in human peripheral blood after fractionation on discontinuous gradients of albumin: the cellular defect in X-linked agammaglobulinemia. J. Clin. Invest. 52: 1726-1734.

7. Geha, R. S., and E. Merler, 1974. Response of human thymus-derived $(\mathrm{T})$ and non-thymus derived (B) lymphocytes to mitogenic stimulation in vitro. Eur. J. Immunol. 4: 193-199.
8. Geha, R. S., E. Schneeberger, F. S. Rosen, and E. Merler. 1973. Interaction of human thymus derived and non-thymus derived lymphocytes in vitro: induction of proliferation and antibody synthesis in B lymphocytes by a soluble factor released from antigen-stimulated $\mathrm{T}$ lymphocytes. J. Exp. Med. 138: 1230-1247.

9. Waldmann, T. A., S. Broder, and R. M. Blaese. 1974. Role of suppressor $\mathrm{T}$ cells in the pathogenesis of common variable hypogammaglobulinemia. Lancet. II: 609-613.

10. Terasaki, P. E., and J. D. McCelland. 1974. Microdroplet assay of human serum cytotoxins. Nature (Lond.). 204: 998-1000.

11. Nilsson, K., G. Klein, and W. Henle. 1971. The establishment of lymphoblastoid lines from adult and fetal human lymphoid tissue and its dependence on EBV. Int. J. Cancer. 8: 443-450.

12. Vittetta, S., and J. W. Uhr. 1975. Immunoglobulin receptors revisited. Science (Wash. D. C.). 189: 964-969.

13. Lawton, A. R., R. Asofsky, M. B. Hylton, and M. D. Cooper. 1972. Suppression of immunoglobulin class synthesis in mice. I. Effects of treatment with antibody to $\mu$ chain. J. Exp. Med. 135: 277-297.

14. Blaese, R. M., P. I. Weiden, and I. Koski. 1974. Infectious agammaglobulinemia: transmission of immunodeficiency with grafts of agammaglobulinemic cells. J. Exp. Med. 140: 1097-1101.

15. Press, J. L., N. R. Klinman, and H. O. McDevitt. 1976. Expression of Ia antigens on hapten specific B cells. $J$. Exp. Med. 144: 414-427.

16. Goldmann, A. A., S. E. Ritzmann, and E. W. Houston. 1967. Dysgammaglobulinemic antibody deficiency syndrome. J. Pediatr. 70: 16-27. 